\title{
Effect of Different Land-Use Types on Soil Properties in Cheha District, South-Central Ethiopia
}

\author{
Solomon Kebebew ${ }^{1, *(\mathbb{D}}$, Bobe Bedadi ${ }^{2}{ }^{\mathbb{C}}$, Teklu Erkossa $^{3}$, Fantaw Yimer $^{4}$ and Lemma Wogi $^{2}$ \\ 1 College of Agriculture and Natural Resource, Wolkite University, Wolkite P.O. Box 07, Ethiopia \\ 2 College of Agriculture and Environmental Sciences, Haramaya University, Dire Dawa P.O. Box 138, Ethiopia; \\ bobedadi2009@gmail.com (B.B.); 1.wogi@yahoo.com (L.W.) \\ 3 Internationale Zusammenarbeit (GIZ) GmbH, City Addis Ababa P.O. Box 5689, Ethiopia; Teklu68@gmail.com \\ 4 Wondo Genet College of Forestry and Natural Resources, Hawassa University, Awassa P.O. Box 128, Ethiopia; \\ fantawyimer2003@gmail.com \\ * Correspondence: solomonkw2012@gmail.com
}

Citation: Kebebew, S.; Bedadi, B.;

Erkossa, T.; Yimer, F.; Wogi, L. Effect of Different Land-Use Types on Soil Properties in Cheha District, South-Central Ethiopia. Sustainability 2022, 14, 1323. https://doi.org/ $10.3390 /$ su14031323

Academic Editor: Sean Clark

Received: 13 August 2021

Accepted: 19 October 2021

Published: 25 January 2022

Publisher's Note: MDPI stays neutral with regard to jurisdictional claims in published maps and institutional affiliations.

Copyright: (C) 2022 by the authors. Licensee MDPI, Basel, Switzerland. This article is an open access article distributed under the terms and conditions of the Creative Commons Attribution (CC BY) license (https:/ / creativecommons.org/licenses/by/ $4.0 /)$.

\begin{abstract}
Land-use changes under poor management practices are among the major causes of decline in soil fertility and agricultural productivity in south-central Ethiopia. Therefore, the study of soil properties variations across land-use types will have implications for planning proper soil management strategies. This study assessed the effects of land-use types on soil physicochemical properties in the Cheha district, south-central Ethiopia. Seven land-use types, eucalyptus plantation, cultivated, grazing, shrub, enset (Ensete ventricosum), khat (Chata edulis), and natural forest, were considered in describing soil fertility. A total of 21 soil samples $(0-20 \mathrm{~cm}$ depth) were collected randomly from three representative soil sampling plots across each land-use type and examined for their analysis of soil physicochemical properties. Results showed that land-use changes induced significant $(p<0.05)$ differences in the soil OC, total $\mathrm{N}, \mathrm{CEC}, \mathrm{pH}$, aluminum saturation, and Fe among land-use types were observed. Soils under eucalyptus plantation were considerably low in the sand $(23.44 \%)$, silt $(24.00 \%)$, and available water content $(111.13 \mathrm{~mm} / \mathrm{m})$, whereas high in clay $(52.56 \%)$ content and bulk density $\left(1.39 \mathrm{~g} \mathrm{~cm}^{-3}\right)$ as compared to enset land-use type. Compared to natural forest, soils under enset land-use type were high in soil OC (2.41\%), total N $(0.23 \%)$, and CEC $\left(37.61 \mathrm{cmol}^{(+)} \mathrm{kg}^{-1}\right.$ ) followed by khat land-use. Correlation analysis also showed a highly significant positive relationship between soil OC and CEC but negative with bulk density, soil $\mathrm{pH}$, and aluminum saturation. Total $\mathrm{N}$ in eucalyptus plantation, cultivated, khat, and enset lands were depleted by $56.0 \%, 40.0 \%, 36.0 \%$, and $8.0 \%$, respectively. Relative to forest land, lower exchangeable $\mathrm{Ca}, \mathrm{Mg}$, and $\mathrm{Na}$ contents were recorded in soils of cultivated land use. The extractable Fe, $\mathrm{Mn}$, and $\mathrm{Zn}$ contents of soils were generally high and are not limiting for crop production. The intensive exploitation of land resources and improper soil management systems in the area could be the major factors for variations in soil properties across land-use types. Therefore, there is a need to develop integrated soil management practices that could help to restore soil nutrients and thereby minimize the continuing soil degradation for sustainable agricultural productivity.
\end{abstract}

Keywords: land-use types; soil properties; soil degradation; eucalyptus species

\section{Introduction}

Soil is the foundation resource for nearly all land uses, and the most important component of sustainable agriculture [1]. Land degradation caused by inappropriate land use is a worldwide problem that has attracted attention in sustainable agricultural production systems. The unusual land management practices can lead to a loss in potential soil nutrients and soil quality, thereby affecting agricultural production, food security, and livelihoods [2]. The growing population and increasing socio-economic necessities create pressure on land use and land cover, resulting in unplanned and uncontrolled changes in land use [3]. This rapid increase in population has led to diminishing cultivable land, 
depletion of soil nutrients, and loss of soil productivity as a result of soil erosion. The main consequences of inappropriate land-use changes are land degradation and soil quality deterioration through loss of vegetative cover [4]. For instance, the land-use conversion of natural grassland and forest ecosystems into arable agriculture results in the loss of $30 \%$ of soil organic carbon [5].

Land-use changes with widespread poor agricultural practice, insecure land tenure, and high population pressure have acted more indirectly as driving forces for land degradation [6]. Land-use change in tropical ecosystems could cause significant modifications in soil properties, stressing the effect of this phenomenon on the ecosystem; Offiong and Iwara [7] investigated that land-use change modifications are rapid biologically and chemically than physically. Research has shown a linkage between land uses and soil properties, particularly with soil nutrients and carbon sequestrations. It can noticeably influence soil physicochemical properties because of different anthropogenic activities, indicating a linkage between land uses and soil properties [8]. The assumption of the sustainability of agricultural ecosystems depends to a great extent on the maintenance of soil physicochemical properties [9].

In Ethiopia, poor land management practices by human activities will accelerate soil erosion that poses a threat to agricultural productivity [10]. For instance, Erkossa et al. [11] revealed that about 1.5 to 3 billion tons of soils are lost from different land cover types every year. This depletion of soil nutrients and changes in soil quality indicators is largely recognized as a principal cause for soil quality loss aggravated by the effect of inappropriate land uses in developing countries, such as Ethiopia [12]. The conversion of native forest to agricultural land use has accelerated and featured in the development of Ethiopian landscapes and has contributed to the widespread occurrence of degraded land across most parts of the country [9]. Regional differences in soil properties, population density, climate, socio-economic factors, and cultural practices have imposed the changes or exclusion of some land uses from specific location.

Several studies [13-16] have considered the effects of land use and their management on soil properties. For instance, widespread poor agriculture activities, including intensive tillage, lack of appropriate soil conservation measures, and cropping practice are also contributing factors [14,15]. Furthermore, Mulugeta [15] reported that land-use changes significantly influence soil proprieties, such as available $\mathrm{P}$ and $\mathrm{K}$, exchangeable bases, and CEC in the Southern Highlands of Ethiopia. Fikadu et al. [16] have considered the effects of land use and their management on soil properties. The authors of [17] have observed the impacts of different land uses on soil qualities and that the rate of soil quality degradation depends on land use systems, soil types, topography, and climatic conditions. Moreover, Yimer et al. [18] compared croplands, forestlands, and grazing lands and found significant changes in selected physical and chemical in the southeastern highlands of Ethiopia. Understanding the distribution and properties of soils is necessary to planning and implementing sustainable land use and/or rehabilitation of degraded lands [19]. Therefore, to identify the influence of land uses on the soil properties as well as the fertility status of the soils, assessing land-use-induced changes in soil properties is critical for sustainable soil productivity.

Generally, a sound understanding of land use and management effects on soil properties provides an opportunity to evaluate the sustainability of land-use systems [20]. In the study area, human activities, including different improper agriculture practices coupled with the intensive expansion of eucalyptus tree plantation, are cause for land-use change. Moreover, practicing such activities along undulated landform have an impact on prevailing land management systems that exacerbates the land-use changes, which consequently affects agricultural productivity as well as environmental quality. Therefore, the objective of this study was to examine the effect of land-use changes on selected soil physicochemical properties of the Cheha district, Ethiopia. 


\section{Materials and Methods}

\subsection{Description of the Study Area}

The study was conducted in the Cheha district, located in Guraghe Zone, Southern Nations, Nationalities, and Peoples' Regional (SNNPR) State of Ethiopia (Figure 1). Geographically, it extends from $08^{\circ} 05^{\prime} 30^{\prime \prime} \mathrm{N}$ to $08^{\circ} 06^{\prime} 0^{\prime \prime} \mathrm{N}$ latitude and $37^{\circ} 58^{\prime} 30^{\prime \prime} \mathrm{E}$ to $37^{\circ} 59^{\prime} 0^{\prime \prime}$ E longitude with altitude ranging from 1717 to $2659 \mathrm{~m}$ above sea level (m a.s.l) and covering an area of 25,876 ha.

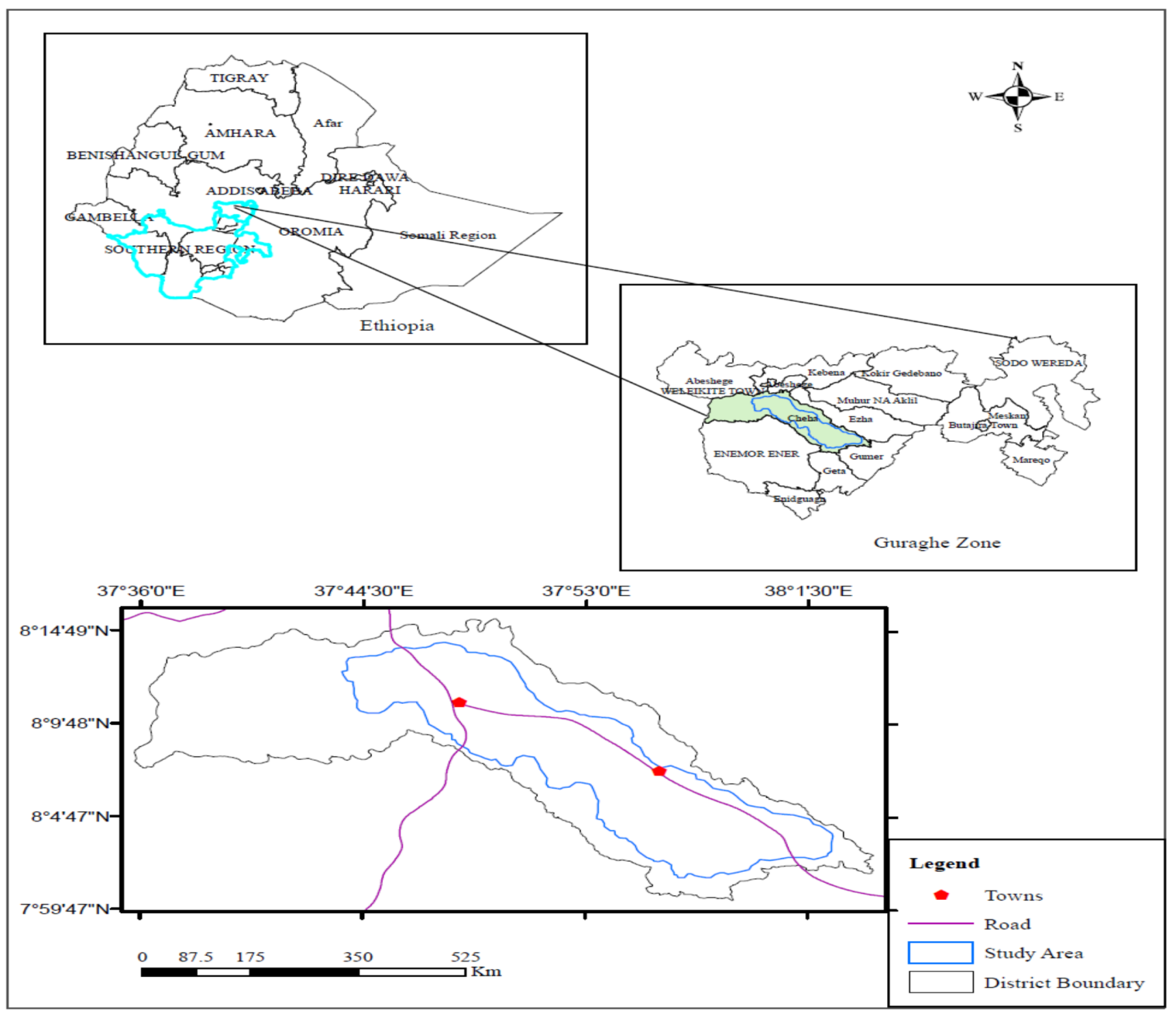

Figure 1. Location of the study area.

The area has three agro-ecological zones of Dega, Waina-dega, and Kolla [21] with an average landholding of 0.5 ha per household head. The study area is characterized by a mono-modal (one mode of rain per year) rainfall pattern with a mean annual rainfall of $1143 \mathrm{~mm}$, the mean annual minimum $\left(11^{\circ} \mathrm{C}\right)$, and maximum $\left(25^{\circ} \mathrm{C}\right)$ temperatures (Figure 2). The area is usually drained by many streams of which Megecha, Gotam, and Gogab are the main ones that flow into the area while Wabe, Wunke, and Kinke are shading to the Omo-Gibe basin. The district is known for its enset based farming system in which enset is the dominant crop grown in the main and short rainy season. The main land-use system of the area is enset-based farming system per household dominantly at farmstead and grazing landholdings. The major annual and perennial crops grown during the main and short rainy season include maize (Zea mays L.), teff (Eragrotis teff L.), 
potato (Solanum tuberosum L.), barley (Hordem vulgare L.), wheat (Triticum aestivum L.), and tomato (Lycopersicum esculentum L.), enset (Ensete ventricosum), khat (Chata edulis L.), and coffee (Coffee arabica L.). In addition, eucalyptus tree plantations (Eucalyptus camaldulensis L. and Eucalyptus globulus L.) have been dominantly planted for their cash income and are expanding to agricultural land areas [21].

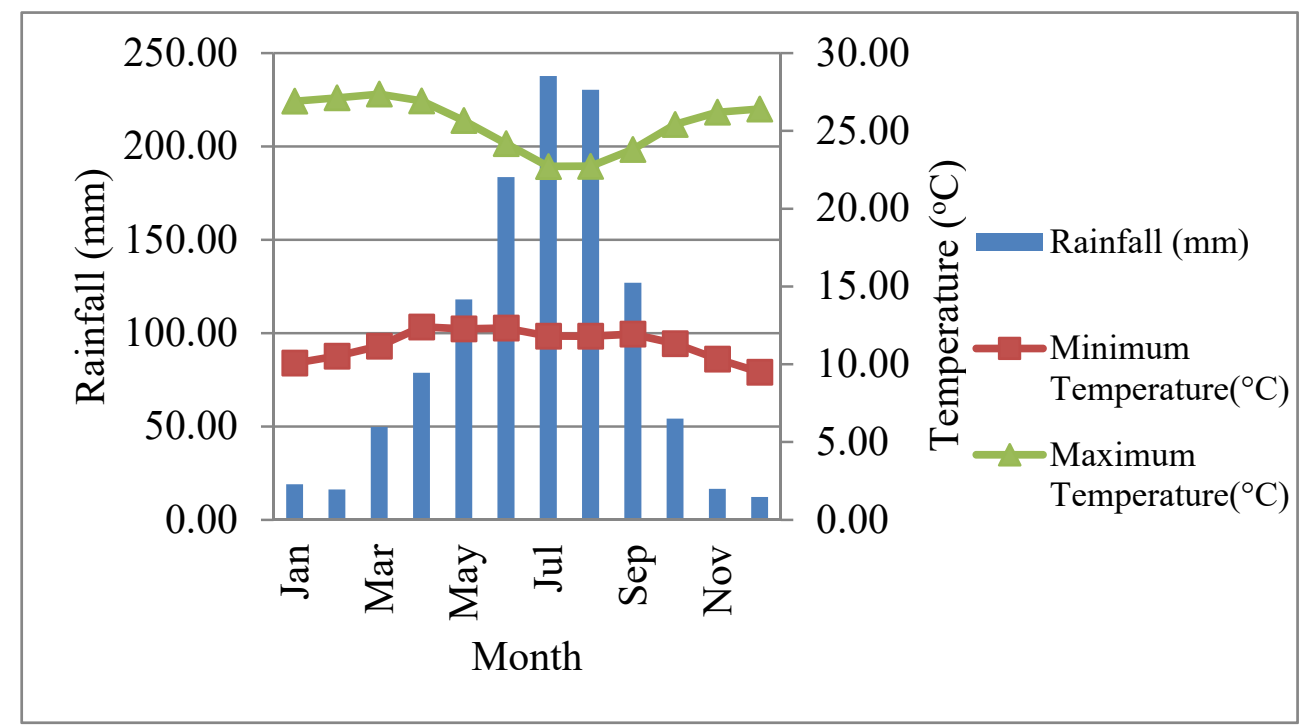

Figure 2. Mean monthly rainfall, maximum and minimum temperatures (1995-2015). Source: (Imdibir Meteorological Station).

\subsection{Site Selection and Descriptions of Land-Use Types (LUTs)}

Preliminary investigations of the physiographic features of the site were made through a reconnaissance survey using a base map (1:50,000 scale) prepared by the Ethiopian mapping agency. Through consultation with farmers, elders, and developmental agents, the historical background of the existing land-use types (LUTs), cropping activity, and management practices were explored and described. This was followed by field observation and informal discussion, which led to the identification of seven land-use types. In addition, the land-use types were selected based on their differences in land management practices and associated activities including the historical and existing information. Moreover, among adjacent land-use types, differences in soil type and slope gradient (topography) of the study area were taken into account to the extent of minimizing these variations. Accordingly, the selected land-use types for the determination of soil physicochemical properties were: eucalyptus plantation (EPL), grazing (GL), cultivated (CL), shrubland (SL), natural forest (NFL), enset plantation (EL), and khat plantation (KL) as described in (Table 1).

\subsection{Soil Sampling, Processing, and Analysis}

Three representative soil sampling plots adjacent to each other were identified and marked across each land-use type for soil samples collection. From each LUT adjacent sampling sites of $50 \mathrm{~m} \times 50 \mathrm{~m}$ plot area were considered for auguring, that each LUT had three replicated plots (randomized) about $100 \mathrm{~m}^{2}$ area. Following this, representative soil sampling points were randomly selected and soil samples $(0-20 \mathrm{~cm}$ depth, common ploughing soil depth) [22] were collected from each soil sampling point (of adjacent sampling site) of respective land-use type, and a composite soil sample was prepared from randomly collected sub-samples (10-15 samples). 
Table 1. Description of the selected land-use types evaluated for soil physicochemical properties.

\begin{tabular}{|c|c|}
\hline Land-Use Types (LUTs) & Description of the Existing LUTs \\
\hline Natural forest land & $\begin{array}{l}\text { The land is covered with native dense tree species with bushes and grasses and } \\
\text { since it is a less disturbed area, it was used as a reference (control). }\end{array}$ \\
\hline Eucalyptus plantation & $\begin{array}{l}\text { The land area is mainly covered with eucalyptus species; established } \\
\text { predominantly on former agricultural farmlands. }\end{array}$ \\
\hline Cultivated land & $\begin{array}{l}\text { Land used for annual rainfed field crops (maize, teff, wheat) at least for } 10 \text { years, } \\
\text { with crop rotation and intensive use of inorganic fertilizer (DAP and Urea). }\end{array}$ \\
\hline Grazing land & Land covered with grass and mainly used for communal grazing by livestock. \\
\hline Shrubland & Areas covered with shrubs and thorny bushes with sparsely scattered trees. \\
\hline Enset land & $\begin{array}{l}\text { The area used for enset plantation at least for } 15 \text { years. The area is located } \\
\text { around the homestead with no inorganic fertilizer inputs and soil conservation } \\
\text { measures, but fresh manure and household wastes are usually applied. }\end{array}$ \\
\hline Khat land & $\begin{array}{c}\text { Field area covered mainly by khat crops intercropped with maize for more than } \\
10-15 \text { years and grown around the homestead or sometimes at fields with } \\
\text { limited tillage operations and soil conservation measures (soil bunds), but fresh } \\
\text { manure has been applied. }\end{array}$ \\
\hline
\end{tabular}

The collected soil samples from selected sampling points of each adjacent sampling site mixed and form a pooled sample of $1 \mathrm{~kg}$. A total of 21 disturbed composited soil samples were collected and prepared for analysis. Similarly, undisturbed soil samples were collected from each LUT at the same soil depth using a core sampler to determine bulk density and soil moisture retention characteristics.

\subsection{Laboratory Analysis of Indicators}

Soil particle size distribution was analyzed using the hydrometric [23] method. Soil bulk density (BD) was determined from undisturbed soil samples collected using a core sampler [24]. Total porosity (TP) was calculated from the values of bulk density (BD) and particle density (PD) [25]. The water content at field capacity (FC) and permanent wilting point (PWP) was measured by pressure plate extraction methods [26]. The available water content (AWC) was computed by subtracting the water content of the permanent wilting point from that of field capacity.

Soil $\mathrm{pH}$ was measured potentiometrically using a digital $\mathrm{pH}$ meter [27]. Soil organic carbon (OC) was determined by wet oxidation method [28]. Total $\mathrm{N}$ was computed using the Kjeldahl method [29]. Exchangeable acidity was extracted by $1 \mathrm{M} \mathrm{KCl}$ solution and determined titrimetrically [30]. Available P was determined by using Olsen extraction methods [31] as soil is treated with ammonium molybdate sulphuric acid with stannous chloride. Cation exchange capacity (CEC) was determined following the ammonium acetate extract method (1N NH $\left.\mathrm{N}_{4} \mathrm{OAc}\right)$ [32]. Exchangeable bases $(\mathrm{Ca}, \mathrm{Mg}, \mathrm{K}$, and $\mathrm{Na}$ ) were determined in ammonium acetate $\left(1 \mathrm{MNH}_{4} \mathrm{OAc}\right)$ extract used for CEC [32]. The exchangeable $\mathrm{Ca}$ and $\mathrm{Mg}$ were measured by atomic absorption spectrophotometer (AAS) and exchangeable $\mathrm{K}$ and $\mathrm{Na}$ were determined by a flame photometer [27]. Percent base saturation (PBS) was calculated as the percentage of the sum of base-forming cations divided by the CEC of the soil and then multiplying by 100 [33]. Extractable micronutrients $(\mathrm{Fe}, \mathrm{Mn}, \mathrm{Cu}$, and $\mathrm{Zn}$ ) were extracted by the diethylenetriaminepenta-acetic acid (DTPA) method and the reading was quantified using AAS [34].

\subsection{Data Analysis}

The data were subjected to one-way analysis of variance (ANOVA) and correlation analysis using a statistical analysis system (SAS) [35]. The mean comparison was conducted using the least significance difference (LSD) test at $p<0.05$. 


\section{Results}

\subsection{Effect of Different Land-Use Types on Soil Physical Properties}

3.1.1. Soil Textural Fractions

Results showed that soil textural fractions were significantly $(p \leq 0.05)$ affected by land-use types (Table 2). The soil was dominated by clay fractions and the textural class was clayey in all soils across different land-use types except in shrubland soil, which was clay loam. The eucalyptus plantation soils were considerably lower in sand and silt than the adjacent soils under natural forests. Compared to natural forest, clay $(52.56 \%)$, silt $(32.50 \%)$, and sand $(31.00 \%)$ contents were higher in the eucalyptus plantation, khat, and shrubland, respectively.

Table 2. Effects of land-use types on physical properties of the soils of the Cheha district.

\begin{tabular}{|c|c|c|c|c|c|c|c|c|c|}
\hline Treatment & Sand & Silt & Clay & $\begin{array}{c}\text { Textural } \\
\text { Class }\end{array}$ & $\begin{array}{c}\text { Bulk } \\
\text { Density } \\
\left(\mathrm{g} \mathrm{cm}^{-3}\right)\end{array}$ & $\begin{array}{c}\text { Total } \\
\text { Porosity } \\
(\%)\end{array}$ & $\begin{array}{c}\mathrm{FC} \\
(\mathrm{mm} / \mathrm{m})\end{array}$ & $\begin{array}{c}\text { PWP } \\
(\mathrm{mm} / \mathrm{m})\end{array}$ & $\begin{array}{l}\text { AWHC } \\
(\mathrm{mm} / \mathrm{m})\end{array}$ \\
\hline \multicolumn{10}{|l|}{ Land-Use Types } \\
\hline Eucalyptus P. & $23.44 \mathrm{c}$ & $24.00 \mathrm{~d}$ & $52.56 \mathrm{a}$ & Clay & $1.39 \mathrm{a}$ & $48.33 \mathrm{~b}$ & $351.1 \mathrm{f}$ & $240.0 \mathrm{e}$ & $111.13 \mathrm{~d}$ \\
\hline Cultivated & $28.84 \mathrm{ab}$ & $30.16 \mathrm{ab}$ & $41.00 \mathrm{~cd}$ & Clay & $1.34 \mathrm{ab}$ & $50.37 \mathrm{~b}$ & $378.9 \mathrm{e}$ & $257.9 \mathrm{~d}$ & $121.03 \mathrm{bc}$ \\
\hline Grazing & $24.10 \mathrm{c}$ & $26.00 \mathrm{~cd}$ & $49.90 \mathrm{ab}$ & Clay & $1.38 \mathrm{ab}$ & $48.89 \mathrm{~b}$ & $388.4 \mathrm{~d}$ & $268.1 \mathrm{c}$ & $120.30 \mathrm{c}$ \\
\hline Shrub & $31.00 \mathrm{a}$ & $30.67 \mathrm{ab}$ & $38.33 \mathrm{~d}$ & Clay loam & $1.32 \mathrm{~b}$ & $49.68 \mathrm{~b}$ & $407.4 \mathrm{~b}$ & $277.4 \mathrm{~b}$ & $130.00 \mathrm{~b}$ \\
\hline N. Forest & $25.83 \mathrm{bc}$ & $28.50 \mathrm{bc}$ & $45.67 \mathrm{cb}$ & Clay & $1.21 \mathrm{c}$ & $54.56 \mathrm{a}$ & $428.6 \mathrm{a}$ & $286.2 \mathrm{a}$ & $142.37 \mathrm{a}$ \\
\hline Enset & $27.00 \mathrm{abc}$ & $32.00 \mathrm{a}$ & $41.00 \mathrm{~d}$ & Clay & $1.22 \mathrm{C}$ & $54.48 \mathrm{a}$ & $405.1 \mathrm{bc}$ & $274.8 \mathrm{bc}$ & $140.33 \mathrm{a}$ \\
\hline Khat & $25.00 \mathrm{bc}$ & $32.50 \mathrm{a}$ & $42.50 \mathrm{~cd}$ & Clay & $1.25 \mathrm{c}$ & $53.31 \mathrm{a}$ & 397.7 c & $269.0 \mathrm{c}$ & $128.70 \mathrm{bc}$ \\
\hline LSD (0.05) & 4.43 & 2.83 & 4.64 & - & 0.06 & 2.55 & 0.65 & 0.84 & 0.90 \\
\hline CV (\%) & 9.39 & 5.44 & 5.88 & & 2.59 & 2.78 & 1.74 & 3.29 & 3.96 \\
\hline SE & 1.44 & 0.92 & 1.51 & - & 0.02 & 0.83 & 0.39 & 0.50 & 0.29 \\
\hline
\end{tabular}

Means within a column followed by the same letter are not significantly different at $(p \leq 0.05)$; LSD = least significant difference; $\mathrm{SE}=$ standard error; $\mathrm{CV}=$ coefficient of variation; $\mathrm{FC}=$ field capacity; $\mathrm{PWP}=$ permanent wilting point; $\mathrm{AWHC}=$ available water holding capacity; Eucalyptus $\mathrm{P} .=$ eucalyptus plantation; N. Forest $=$ natural forest.

\subsubsection{Soil Bulk Density, Total Porosity, and Soil Water Characteristics}

The result indicated that bulk density and total porosity were significantly $(p \leq 0.05)$ affected by land-use types. The highest $\left(1.39 \mathrm{~g} \mathrm{~cm}^{-3}\right)$ mean value of bulk density was recorded under eucalyptus land use followed by soils under grazing and cultivated land uses; while the lowest $\left(1.21 \mathrm{~g} \mathrm{~cm}^{-3}\right)$ mean bulk density value was recorded in soil under forest and enset land-use types (Table 2).

The total porosity of the soil ranged from $48.33 \%$ to $54.56 \%$ across all land-use types (Table 2). The highest (54.56\%) total porosity was computed for soils under forest followed by the enset plantation, while the lowest $(48.33 \%)$ was under eucalyptus plantation. Soil water retention at both FC and PWP was significantly $(p \leq 0.05)$ affected by the land-use types (Table 2). The water retained at FC and PWP was higher in soils of forest land than those in other land-use types. The recorded soil water retained at FC $(428.60 \mathrm{~mm} / \mathrm{m})$ and PWP $(286.20 \mathrm{~mm} / \mathrm{m})$ were the highest under forest land soils. Similarly, the highest $(142.37 \mathrm{~mm} / \mathrm{m})$ AWHC was also exhibited under soils of the same land-use type followed by enset and khat (Table 2).

\subsection{Effect of Different Land-Use Types on Soil Chemical Properties \\ 3.2.1. Soil $\mathrm{pH}$, Exchangeable Acidity, and Aluminum Saturation}

The result depicted that soil $\mathrm{pH}\left(\mathrm{H}_{2} \mathrm{O}\right)$, exchangeable acidity, electrical conductivity, and $\mathrm{Al}$ saturation percentage were significantly $(p \leq 0.05)$ affected by land-use types. The soil $\mathrm{pH}\left(1: 2.5 \mathrm{H}_{2} \mathrm{O}\right)$ of the study area was within the range of strongly acid to moderately acid [36]. The highest mean soil $\mathrm{pH}-\mathrm{H}_{2} \mathrm{O}$ (5.92) was recorded under khat land-use type, whereas the lowest mean (5.01) value was in the soils of forest land (Table 3). Exchangeable acidity was significantly higher $\left(4.89 \mathrm{cmol}(+) \mathrm{kg}^{-1}\right)$ under eucalyptus plantation followed by shrub and cultivated land uses as compared to the other land-use types. The highest 
(25.42\%) percentage of $\mathrm{Al}$ saturation (ASP) was obtained under eucalyptus plantations, while the lowest $(0.35 \%)$ was in the soils of khat land.

Table 3. Effects of land-use types on selected chemical properties of the soils of the Cheha district.

\begin{tabular}{|c|c|c|c|c|c|c|c|c|}
\hline Treatment & $\mathrm{pH}-\mathrm{H}_{2} \mathrm{O}$ & $\begin{array}{c}\mathrm{Al} \\
\left(\mathrm{cmol}(+) \mathrm{kg}^{-1}\right)\end{array}$ & $\begin{array}{c}\text { EA } \\
\left(\mathrm{cmol}^{(+)} \mathrm{kg}^{-1}\right)\end{array}$ & ASP & SOC (\%) & $\begin{array}{c}\text { Total N } \\
(\%)\end{array}$ & C:N Ratio & $\begin{array}{c}\text { Available P } \\
\left(\mathrm{mg} \mathrm{kg}^{-1}\right)\end{array}$ \\
\hline \multicolumn{9}{|l|}{ Land-Use Types } \\
\hline Eucalyptus P. & $5.54 \mathrm{ab}$ & $3.47 \mathrm{a}$ & $4.89 \mathrm{a}$ & $25.42 \mathrm{a}$ & $1.32 \mathrm{e}$ & $0.11 \mathrm{c}$ & $12.09 \mathrm{a}$ & $9.52 \mathrm{ab}$ \\
\hline Cultivated & $5.65 \mathrm{ab}$ & $2.17 \mathrm{c}$ & $3.18 \mathrm{c}$ & $16.81 \mathrm{c}$ & $1.51 \mathrm{~d}$ & $0.15 \mathrm{~b}$ & $10.09 \mathrm{c}$ & $9.73 \mathrm{a}$ \\
\hline Grazing & $5.40 \mathrm{bc}$ & $1.57 \mathrm{~d}$ & $2.41 \mathrm{~d}$ & $9.49 \mathrm{~d}$ & $1.40 \mathrm{de}$ & $0.12 \mathrm{c}$ & $11.34 \mathrm{abc}$ & $6.75 c$ \\
\hline Shrub & $5.53 \mathrm{ab}$ & $3.08 \mathrm{~b}$ & $4.22 \mathrm{~b}$ & $20.10 \mathrm{~b}$ & $1.89 \mathrm{c}$ & $0.15 \mathrm{~b}$ & $12.34 \mathrm{a}$ & $9.50 \mathrm{ab}$ \\
\hline N. Forest & $5.01 \mathrm{c}$ & $0.59 \mathrm{e}$ & $1.42 \mathrm{e}$ & $4.99 \mathrm{e}$ & $3.00 \mathrm{a}$ & $0.25 \mathrm{a}$ & $12.21 \mathrm{a}$ & $9.27 \mathrm{ab}$ \\
\hline Enset & $5.47 \mathrm{abc}$ & $0.17 \mathrm{f}$ & $0.68 \mathrm{f}$ & $0.93 \mathrm{f}$ & $2.41 \mathrm{~b}$ & $0.23 \mathrm{a}$ & $10.47 b c$ & $8.52 \mathrm{abc}$ \\
\hline Khat & $5.92 \mathrm{a}$ & $0.05 \mathrm{f}$ & $0.21 \mathrm{~g}$ & $0.35 \mathrm{f}$ & $1.95 \mathrm{c}$ & $0.16 \mathrm{~b}$ & $11.97 \mathrm{ab}$ & $7.20 \mathrm{bc}$ \\
\hline LSD (0.05) & 0.51 & 0.19 & 0.28 & 1.21 & 0.17 & 0.02 & 1.55 & 2.39 \\
\hline CV (\%) & 5.16 & 6.75 & 6.42 & 6.09 & 4.83 & 5.58 & 7.59 & 15.57 \\
\hline SE & 0.16 & 0.06 & 0.09 & 0.39 & 0.05 & 0.01 & 0.50 & 0.78 \\
\hline
\end{tabular}

Means within a column followed by the same letter are not significantly different at $(p \leq 0.05)$; LSD = least significant difference; $\mathrm{CV}=$ coefficient of variation; $\mathrm{SE}=$ standard error; $\mathrm{EA}=$ exchangeable acidity; $\mathrm{ASP}=\mathrm{Al}$ saturation percentage; Eucalyptus P. = eucalyptus plantation; N. Forest = natural forest.

\subsubsection{Soil Organic Carbon, Total N, C:N Ratio, and Available P}

The effects of the land-use types on soil chemical properties are presented in Table 3. Significant differences $(p \leq 0.05)$ in OC content, Total $\mathrm{N}$, and available $\mathrm{P}$ were observed with land-use types. The soil OC content was highest (3.00\%) under soils of forest land followed by enset $(2.41 \%)$ land use.

Total nitrogen content ranged from $0.11 \%$ to $0.25 \%$ across land-use types. The highest total $\mathrm{N}$ content was observed under forest land followed by enset field, whereas the lowest $(0.11 \%)$ was recorded under eucalyptus plantation. The C:N ratio of the studied soils ranged from 10.09 to 12.34 . The highest mean soil C:N ratio (12.3) was observed in shrub followed by forest (12.2) land-use types. The mean value of available P content of soils for cultivated land was higher $\left(9.73 \mathrm{mg} \mathrm{kg}^{-1}\right)$ than other land use, with a lower value observed in grazing $\left(6.75 \mathrm{mg} \mathrm{kg}^{-1}\right)$ soils (Table 3$)$.

\subsubsection{Soil Exchangeable Bases, Cation Exchange Capacity, and Soil Micronutrients}

Variations in exchangeable bases were significant $(p \leq 0.05)$ with land-use types (Table 4). The observed values of exchangeable Ca were the highest $\left(10.94 \mathrm{cmol}(+) \mathrm{kg}^{-1}\right)$ under the enset land followed by the khat and forest land soils, whereas the lowest exchangeable $\mathrm{Ca}$ was recorded cultivated land use type. The content of exchangeable $\mathrm{K}$ varied from (0.71 to $\left.1.02 \mathrm{cmol}(+) \mathrm{kg}^{-1}\right)$ and $\mathrm{Na}\left(0.19\right.$ to $\left.0.31 \mathrm{cmol}(+) \mathrm{kg}^{-1}\right)$.

Cation exchange capacity varied significantly $(p \leq 0.05)$ with land-use types and ranged between 24.93 to $39.73 \mathrm{cmol}(+) \mathrm{kg}^{-1}$ (Table 4). According to Hazelton and Murphy's [37] classification, CEC of the soil across all land-use types is characterized by moderate to high. A significantly higher $\left(39.73 \mathrm{cmol}(+) \mathrm{kg}^{-1}\right)$ value was observed under the natural forest followed by enset and khat land uses, but the lowest $\left(24.93 \mathrm{cmol}(+) \mathrm{kg}^{-1}\right)$ value of CEC was under eucalyptus plantation. The soils of the study area were generally high in extractable $\mathrm{Fe}, \mathrm{Mn}$, and $\mathrm{Zn}$ contents, but medium for $\mathrm{Cu}$, following a consistent trend with the acidic soil reaction. 
Table 4. Soil exchangeable bases, CEC, and micronutrients as affected by land-use types.

\begin{tabular}{|c|c|c|c|c|c|c|c|c|c|c|}
\hline \multirow[b]{2}{*}{ Treatment } & $\mathrm{Ca}$ & $\mathrm{Mg}$ & $\mathbf{K}$ & $\mathrm{Na}$ & CEC & \multirow{2}{*}{$\begin{array}{c}\text { PBS } \\
(\%)\end{array}$} & \multicolumn{4}{|c|}{ Extractable Micronutrients $\left(\mathrm{mg} \mathrm{kg}^{-1}\right)$} \\
\hline & \multicolumn{5}{|c|}{$\left(\mathrm{cmol}(+) \mathrm{kg}^{-1}\right)$} & & $\mathbf{F e}$ & Mn & $\mathrm{Cu}$ & Zn \\
\hline \multicolumn{11}{|l|}{ Land-Use Types } \\
\hline Eucalyptus P. & $5.21 \mathrm{~cd}$ & $2.71 \mathrm{a}$ & $0.78 \mathrm{ab}$ & $0.24 a b c$ & $24.93 c$ & $36.08 \mathrm{bcd}$ & $9.86 \mathrm{a}$ & $4.66 \mathrm{a}$ & $3.44 \mathrm{c}$ & $2.60 \mathrm{c}$ \\
\hline Cultivated & $4.59 \mathrm{~d}$ & $2.61 \mathrm{a}$ & $0.85 \mathrm{ab}$ & $0.22 \mathrm{bc}$ & $29.75 \mathrm{~b}$ & $27.96 \mathrm{~d}$ & $5.94 \mathrm{c}$ & $4.50 \mathrm{a}$ & $3.51 \mathrm{bc}$ & $2.63 c$ \\
\hline Grazing & $9.46 \mathrm{ab}$ & $2.72 \mathrm{a}$ & $0.88 \mathrm{ab}$ & $0.19 c$ & $28.34 \mathrm{bc}$ & $47.73 \mathrm{a}$ & $6.94 \mathrm{c}$ & $4.94 \mathrm{a}$ & $3.05 c$ & $2.87 \mathrm{bc}$ \\
\hline Shrub & $7.32 \mathrm{bcd}$ & $3.06 \mathrm{a}$ & $0.79 \mathrm{ab}$ & $0.28 \mathrm{ab}$ & $29.38 \mathrm{bc}$ & $38.96 \mathrm{abc}$ & $9.34 \mathrm{a}$ & $4.97 \mathrm{a}$ & $4.41 \mathrm{ab}$ & $3.60 \mathrm{a}$ \\
\hline N. Forest & $7.83 \mathrm{abc}$ & $3.38 \mathrm{a}$ & $1.02 \mathrm{a}$ & $0.23 \mathrm{bc}$ & $39.73 \mathrm{a}$ & $31.17 \mathrm{~cd}$ & $7.43 \mathrm{~b}$ & $4.39 \mathrm{a}$ & $3.53 \mathrm{bc}$ & $3.08 \mathrm{abc}$ \\
\hline Enset & $10.94 \mathrm{a}$ & $3.44 \mathrm{a}$ & $0.89 \mathrm{ab}$ & $0.26 a b c$ & $37.61 \mathrm{a}$ & $41.21 \mathrm{ab}$ & $7.73 \mathrm{~b}$ & $4.49 \mathrm{a}$ & $4.93 \mathrm{a}$ & $3.46 \mathrm{ab}$ \\
\hline Khat & $9.30 \mathrm{ab}$ & $3.54 \mathrm{a}$ & $0.71 \mathrm{~b}$ & $0.31 \mathrm{ab}$ & $31.30 \mathrm{~b}$ & $44.32 \mathrm{ab}$ & $9.52 \mathrm{a}$ & $5.18 \mathrm{a}$ & $3.89 \mathrm{bc}$ & $3.47 \mathrm{ab}$ \\
\hline LSD (0.05) & 3.15 & 1.00 & 0.28 & 0.08 & 4.57 & 8.78 & 1.29 & 1.5 & 0.95 & 0.69 \\
\hline CV (\%) & 22.67 & 18.36 & 18.87 & 18.25 & 8.14 & 12.92 & 8.93 & 17.79 & 13.98 & 12.47 \\
\hline SE & 1.02 & 0.33 & 0.09 & 0.03 & 1.48 & 2.85 & 0.42 & 0.49 & 0.31 & 0.22 \\
\hline
\end{tabular}

Means within a column followed by the same letter are not significantly different at ( $p \leq 0.05)$; LSD = least significant difference; $\mathrm{SE}$ = standard Error; $\mathrm{CV}=$ coefficient of variation; $\mathrm{PBS}$ = percent base saturation; Eucalyptus P. = eucalyptus plantation; N. Forest $=$ natural forest.

The extractable Fe and Mn ranged from (5.94-9.86 $\left.\mathrm{mg} \mathrm{kg}^{-1}\right)$ and $\mathrm{Mn}\left(4.39-5.18 \mathrm{mg} \mathrm{kg}^{-1}\right)$ across land-use types, respectively (Table 4). Relatively higher levels of $\mathrm{Fe}, \mathrm{Mn}, \mathrm{Cu}$, and $\mathrm{Zn}$ were observed in soil under natural forest and enset land uses compared to other land-use types. Similarly, $\mathrm{Cu}$ and $\mathrm{Zn}$ contents showed variations $\left(3.05-4.93 \mathrm{mg} \mathrm{kg}^{-1}\right)$ for $\mathrm{Cu}$ and (2.60 to $3.60 \mathrm{mg} \mathrm{kg}^{-1}$ ) for $\mathrm{Zn}$ with land-use types.

\section{Discussion}

\subsection{Effect of Different Land-Use Types on Soil Properties \\ 4.1.1. Soil Textural Fractions}

The results showed that the soil properties varied across different land-use types in the Cheha district. The variations in soil physicochemical properties could be attributed to different soil management practices across land-use types. A relatively higher clay fraction was found in soils of all land-use types followed by silt fraction, indicating that the soil in the study area is dominated by fine fractions. For instance, under soils of the eucalyptus plantation and grazing land-uses, the silt and sand contents are likely to be low, which might be removed through processes of erosion from surface layers. Eyayu et al. [38] reported that soils with high clay content have sufficient particle-to-particle contact points to form strong bonds when the soil dries.

\subsubsection{Soil Bulk Density, Total Porosity, and Soil Water Characteristics}

The mean value of bulk density was higher in cultivated land use, which could be attributed to the intensive tillage practices that may temporarily compact the tilled soil layer and increase in bulk density through time, and the relative lower soil organic matter (SOM) content due to the removal of crop residues. Moreover, the continuous exposure of soil under the eucalyptus plantation to the direct impact of raindrops causes soil compaction through the instability of soil structure also contributed to the higher bulk density. Soil compaction resulting from intensive cultivation and overgrazing might have caused higher bulk density values in both land-uses compared to others. The observed lowest bulk density in soils under the natural forest could largely be attributed to its highest soil SOC content. Soil compaction resulting from intensive cultivation and overgrazing might have caused higher bulk density values in both land-uses compared to others. This result is in agreement with the findings of Getahun et al. [39] who reported lower bulk density values under enset farms in the south-central highlands of Ethiopia. Bulk density showed a negative correlation with soil OC, and positively correlated with clay content (Table 5). This could be related to the higher soil OC. Poor soil aggregation possibly accounted for the higher bulk density under the eucalyptus plantation and cultivated land compared to the natural forest. 
The higher porosity in enset land soils is consistent with greater input of OM contributing organic residues and leaves of enset crops. Such variations in total porosity among land uses might be attributed to differences in soil OM contents. For instance, a higher OM content in forest and enset land could increase in porosity of their soil. Soil water holding capacity is highly affected by soil management practices, due to the modification of soil structure as well as texture. The variation in water content both at FC and PWP might be due to differences in their soil particles and soil OM content. Lower soil OM content in eucalyptus plantation, cultivated, and grazing land uses increased soil bulk density and decreased soil porosity; this would result in poor macropores and soil structure and, as a result, lowers the water retention capacity of the soil. Moreover, lower soil water content was observed at three water potentials in soils of eucalyptus land use; this could be attributed to high consumption of available water by eucalyptus woodlots and low OM contents of the soils (Table 2).

\subsubsection{Soil $\mathrm{pH}$, Exchangeable Acidity, and Aluminum Saturation}

Soil acidity is also a consequence of the leaching of basic cations in soils due to high rainfall, which results in rapid erosion. The soil $\mathrm{pH}\left(1: 2.5 \mathrm{H}_{2} \mathrm{O}\right)$ of the study area was within the range of strongly acid to moderately acid [36]. The highest soil $\mathrm{pH}$ value indicated in Table 3 under khat plantation could be attributed to a higher amount of exchangeable bases as a result of the application of household wastes such as wood ash as the plots are often located close to habitations. Soil acidity affects the process of other nutrient transformations, solubility, or availability of many plant-essential nutrients.

The results are in agreement with the findings of Alemayehu and Sheleme [40] who reported higher values of soil $\mathrm{pH}$ under enset plantation as compared to land plots located far from the homestead. Soils under khat land had the lowest value of exchangeable acidity. These mean values of exchangeable acidity noticeably varied among land-use types, which suggests that changes in land use influence exchangeable $\mathrm{Al}$ and $\mathrm{H}$. The result concurs with studies by Temesgen et al. [41] who reported the highest exchangeable acidity under soils of eucalyptus plantations compared to grassland and cropland. The $\mathrm{pH}$ values under eucalyptus plantations, grazing, and natural forest soils were below 5.5 , which revealed that the exchangeable sites were primarily occupied by Al cations, subsequently a high concentration of exchangeable $\mathrm{Al}^{3+}$ in the soils. The marked reduction of exchangeable $\mathrm{Al}$ and $\mathrm{Al}$ saturation in the soils of khat and enset land might be ascribed to relative higher $\mathrm{pH}$ and soil OM that probably forms a complex with Al. In general, more highly weathered soils tend to have lower $\mathrm{OC}$ and nutrient contents and lower $\mathrm{pH}$ levels, and higher acidity (as measured by exchangeable Al levels) than soils in less intensively weathered regions of the country [42]. 
Table 5. Correlations coefficients among soil physicochemical properties under different land-use types.

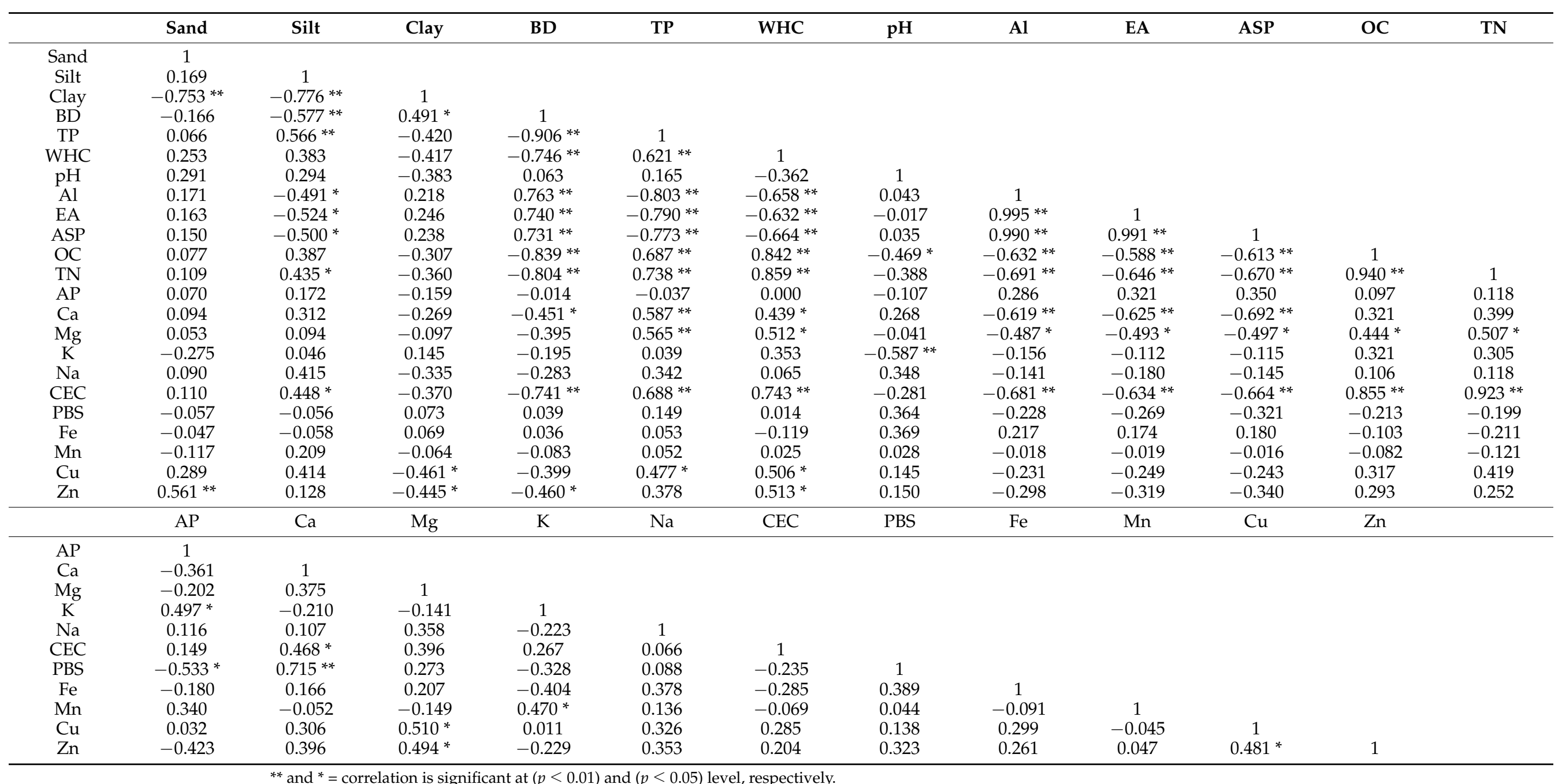




\subsubsection{Soil Organic Carbon, Total N, C:N Ratio, and Available P}

A significant decrease in OC content was observed in the eucalyptus plantation, grazing land, and cultivated land uses compared to soils under enset and khat land uses. This could be attributed to the high demand of eucalyptus trees for soil OC, overgrazing, and continuous cultivation that aggravates OM oxidation. For instance, the decline in soil OM content in the cultivated land might have been aggravated by insufficient inputs of organic substrates. A similar result by [38] also reported lower levels of soil OM under cultivated, grazing, or degraded land than in the forest land. The higher OC contents in enset land could be associated with continuous inputs of the house refuses. In general, the OC content under soils of land-use types is characterized by low to moderate [36]. A similar result by Getahun et al. [39] showed that higher OC and TN under the soil of enset farms as compared to other land uses in Butajira in the central highlands of Ethiopia. The lowest OC under grazing and cultivated land showed the severity of soil degradation under this land-use utilization.

Considering soils of forest land as a comparison for different land uses, total $\mathrm{N}$ content in eucalyptus, cultivated, khat, and enset lands depleted by $56.00 \%, 40.00 \%, 36.00 \%$, and $8.00 \%$, respectively (Table 3). The result is consistent with Achalu et al. [9] who reported that conversion of natural forest to different land uses causes a decline of soil OM and total $\mathrm{N}$ in the topsoil layer. The differences in total $\mathrm{N}$ between natural forest and the remaining land uses could be attributed to the reduction in OM inputs, due to disturbance of soil that increases the decomposition rate of soil OM under continuously cropped fields. Eyayu and Mamo [43] also reported that large losses of total $\mathrm{N}$ in the continuously cropped fields compared to soils of forest land in Agedit watershed, northwest. The narrow C:N ratio under soils of grazing and eucalyptus land uses suggests a higher rate of $\mathrm{CO} 2$ elimination that could increase the demand of microbes for $\mathrm{N}$ to supply more than the optimum. The C:N of soils under all land-use types is categorized within the common range (8:1-15:1) as described by [26].

The comparative lower content of available $\mathrm{P}$ in the soils of grazing land-use might be attributed to higher clay content of the soil and inherent P deficiency of the soil. In general, the continuous application of $P$ fertilizers in the cultivated lands led to a higher available $P$ than the uncultivated lands. In addition, soils with higher clay content have the lowest ease of $\mathrm{P}$ release; hence, phosphorus fixation tends to be more pronounced. The result of the present study is consistent with a study by Habtamu et al. [44], who reported a higher available P content in cultivated soil. A similar result was found by Heluf and Wakene [45], who reported that a low concentration of available $\mathrm{P}$ in the uncultivated lands could be due to little or no P fertilizers having been applied.

\subsubsection{Soil Exchangeable Bases, Cation Exchange Capacity, and Soil Micronutrients}

The exchangeable Mg contents among land-use types followed the same trend with Ca. This might be due to losses of harvested parts of plants under cultivated land and leaching of basic cations from topsoils of the eucalyptus plantation and cultivated land. A similar study by [9] also revealed that lower concentrations of exchangeable $\mathrm{Ca}, \mathrm{Mg}$, and $\mathrm{K}$ contents in soils cultivated compared to soils under forest land in the Guto Gida District of Ethiopia. Compared to forest land, the relatively lower concentration of exchangeable $\mathrm{Ca}$, $\mathrm{Mg}$, and Na contents was recorded in soils of cultivated land uses. This could be attributed to the leaching of basic cations from the surface soils of cultivated land. Moreover, the lower exchangeable $\mathrm{Ca}$ and $\mathrm{Mg}$ contents in the cultivated than in the forest land might be due to its continuous losses of basic cations during harvesting through the removal of parts from the cultivated.

In general, exchangeable $\mathrm{Ca}$ and $\mathrm{Mg}$ were the dominant cations in occupying the exchangeable sites of the soils, exclusively $\mathrm{Ca}$ account for the greater part, followed by $\mathrm{Mg}$, $\mathrm{K}$, and $\mathrm{Na}$ in their decreasing order dominating the exchange site in all land uses. A similar study by Heluf and Wakene [45] revealed that variations in the distribution of exchangeable bases depend on the particles size distribution, degree of weathering, soil management 
practices, climatic conditions, and the intensity of cultivation. In general, leaching, limited recycling of crop residues in the soil, continuous cropping, and soil erosion might have contributed to the depletion of basic cations of the soils [43]. A significantly higher value of CEC was in the soils of the natural forest followed by enset and khat land uses (Table 4), this follows the same trend as soil OC contents as depicted by its positive correlation with soil OC (Table 5). The CEC value in the cultivated land use decreased mainly due to the reduction in OM content. The relative amount of CEC in the soil is determined by the amount of colloidal substance (humus) in the soil; therefore, soils containing high OM contents have high CEC. A parallel increment of OC and soil CEC was observed under soils of forest and enset land uses. This result is inconsistent with the findings of [9] who reported the highest CEC value in soils of forest land among the three different land uses in soils of western Oromia, Ethiopia. The higher CEC values under soils of forest and enset land use are usually attributed to the accumulation of high soil OM holding positive cations in the soil irrespective of lower clay contents.

The soils of the study area were generally high in extractable Fe, Mn, and Zn contents, but medium for $\mathrm{Cu}$, consistent with the acidic soil reaction. Concerning land uses, soils under natural forest and enset land use had relatively higher levels of $\mathrm{Fe}, \mathrm{Mn}, \mathrm{Cu}$, and $\mathrm{Zn}$ compared to others. The highest Fe value was in the eucalyptus land soils followed by soils of khat land uses. This result is in agreement with the findings of Mengistu and Dereje [46] who reported lower available micronutrients in the soils of cultivated land compared to other land-use types. The studied soils were above the critical levels, suggesting there is no deficiency of micronutrients; rather, it might be high enough to cause toxicity to plants.

\section{Conclusions}

A substantial variability exhibiting in most soil properties among land-use types was observed that could affect proper soil functions. These findings indicated that soil physicochemical properties under different land-use types had significant changes. Soils collected from the seven land-use types of the Cheha district were dominated by clay fractions and showed marked differences in their major soil nutrients, including soil OC, total N, CEC, and percentage base saturation among land-use types.

Compared to natural forests, eucalyptus plantation followed by free grazing has shown a very pronounced effect on $\mathrm{OC}$, total N, and CEC, whereas soils under enset and khat land-use types were better in their soil nutrient levels, suggesting a continuous input of house refuse around the homestead. Systematic integration of intensive scientific study for site-specific soil nutrients status concerning differing production systems should be considered to reinforce land management strategies. Therefore, improving the existing land-use practices through implementing proper soil management measures as well as introducing the controlled expansion of a fast-growing nature of eucalyptus species plantation and effective use of crop residues could be an advantage to reinstate the deteriorated soil nutrient for sustainable agricultural production and environmental functions.

Author Contributions: Conceptualization, investigation, and writing-original draft preparation S.K.; supervision and writing-review and editing, B.B.; methodology and writing-review and editing, T.E.; methodology and writing-review and editing, F.Y.; methodology and writing-review and editing, L.W. All authors have read and agreed to the published version of the manuscript.

Funding: This research received no external funding.

Institutional Review Board Statement: Not applicable.

Informed Consent Statement: Informed consent was obtained from all subjects involved in the study.

Data Availability Statement: Not applicable.

Acknowledgments: The authors are grateful to the Ministry of Science and Higher Education and Wolkite University for facilitating the study and research work. We are thankful for all assistance and experiences sharing from the developmental agents and farmers in Cheha district. 
Conflicts of Interest: The authors declare no conflict of interest.

\section{References}

1. Mulugeta, D.; Karl, S. Assessment of integrated soil and water conservation measures on key soil properties in south Gondar, north-western Highlands of Ethiopia. J. Soil Sci. Environ. Manag. 2010, 1, 164-176.

2. Perveen, S.; Malik, Z.; Nazif, W. Fertility Status of Vegetable Growing Areas of the Peshawer, Pakistan. Pak. J. Bot. 2010, 46, 1871-1880.

3. Seto, K.C.; Woodcock, C.E.; Song, C.; Huang, X.; Lu, J.; Kaufmann, R.K. Monitoring Land Use Change in the Pearl River Delta Using Landsat TM. Int. J. Remote Sens. 2002, 23, 1985-2004. [CrossRef]

4. Khormali, F.; Ajami, M.; Ayoubi, S.; Srinivasarao, C.; Wani, S.P. Role of deforestation and hillslope position on soil quality attributes of loess-derived soils in Golestan province, Iran. Agric. Ecosyst. Environ. 2009, 134, 178-189. [CrossRef]

5. Bot, A.; Benites, J. The Impotance of Soil Organic Matte Key to Drought-Resistant Soil and Sustained Food and Production; Food and Agriculture Organization of the United Nation: Rome, Italy, 2005.

6. Eleni, Y.; Wolfgang, W.; Michael, E.K.; Dagnachew, L.; Günter, B. Identifying Land Use/Cover Dynamics in the Koga Catchment, Ethiopia, from Multi-Scale Data, and Implications for Environmental Change. Int. J. Geo-Inform. 2013, 2, 302-323.

7. Offiong, R.A.; Iwara, A.I. Quantifying the Stock of Soil Organic Carbon Using Multiple Regression Model in a Fallow Vegetation, Southern Nigeria. Ethiop. J. Environ. Stud. Manag. 2012, 5, 166-172. [CrossRef]

8. Emiru, N.; Gebrekidan, H. Effect of Land Use Changes and Soil Depth on Soil Organic Matter, Total Nitrogen and Available Phosphorus Contents of Soils in Senbat Watershed, Western Ethiopia. J. Agric. Biol. Sci. 2013, 8, $206-212$.

9. Chimdi, A.; Gebrekidan, H.; Kibret, K.; Tadesse, A. Status of selected physicochemical properties of soils under different land use systems of Western Oromia, Ethiopia. J. Biodivers. Environ. Sci. 2012, 2, 57-71.

10. Girmay, G.; Singh, B.R.; Mitiku, H.; Borresen, T.; Lal, R. Carbon stocks in Ethiopian soils in relation to land use and soil management. Land Degrad. Dev. 2008, 19, 351-367. [CrossRef]

11. Erkossa, T.; Stahr, K.; Gaiser, T. Effect of different methods of land preparation on runoff, soil and nutrient losses from a Vertisols in the Ethiopian Highlands. Soil Use Manag. 2005, 21, 253-259. [CrossRef]

12. Hurni, H.; Tato, K.; Zeleke, G. The implications of changes in population, land use, and land management for surface runoff in the Upper Nile Basin Area of Ethiopia. Mt. Res. Dev. 2005, 25, 147-154. [CrossRef]

13. Yimer, F.; Abdelkadir, A. Soil Property Changes Following Conversion of Acacia Woodland into Grazing And Farmlands In The Rift Valley Area Of Ethiopia. Land Degrad. Dev. 2011, 22, 425-431. [CrossRef]

14. Muluneh, M. Eucalyptus Plantations in the Highlands of Ethiopia Revisited: A Comparison of Soil Nutrient Status after the First Coppicing in Southwest Ethiopia; BOKU: Vienna, Austria, 2011.

15. Lemenih, M.; Karltun, E.; Olsson, M. Assessing soil chemical and physical property responses to deforestation and subsequent cultivation in smallholders farming system in Ethiopia. Agric. Ecosyst. Environ. 2005, 105, 373-386. [CrossRef]

16. Getachew, F.; Abdulkadir, A.; Lemenih, M.; Fetene, A. Effects of Different Land use on Soil Physical and Chemical Properties in Wondo Genet Area, Ethiopia. N. Y. Sci. J. 2012, 5, 110-118.

17. Assai, W.N.; Gebrekidan, H. Influence of land management on morphological, physical and chemical properties of some soils of Bako, Western Ethiopia. Agropedology 2003, 13, 1-9.

18. Yimer, F.; Ledin, S.; Abdelkadir, A. Changes in soil organic carbon and total nitrogen contents in three adjacent land use types in the Bale Mountains, South-eastern highlands of Ethiopia. For. Ecol. Manag. 2007, 242, 337-342. [CrossRef]

19. Ashenafi, A.; Abayneh, E.; Beyene, S. Characterizing soils of DelboWegen watershed, Wolaita Zone, southern Ethiopia, for planning appropriate land management. J. Soil Sci. Environ. Manag. 2010, 1, 184-189.

20. Bewket, W. Land Cover Dynamics since the 1950s in Chemoga Watershed, Blue Nile Basin, Ethiopia. Mt. Res. Dev. 2003, 22, 263-269. [CrossRef]

21. CHWAOR (Cheha Woreda Agricultural Office Report). Cheha Woreda Agriculture and Natural Resource Development Department Office Report, Guraghe Zone, Ethiopia; Cheha Woreda Agricultural Office: Imdibir, Ethiopia, 2016.

22. Birhane, G. Soil Quality Assessment Strategies for Evaluating Soil Degradation in Northern Ethiopia. Appl. Environ. Soil Sci. 2014, 2014, 646502.

23. Bouyoucos, G.J. Hydrometer method improved for making particle-size analysis of soils. Agron. J. 1962, 54, 464-465. [CrossRef]

24. Blake, G.R.; Hartge, K.H. Bulk density. In Methods of Soil Analysis: Part 1 Physical and Mineralogical Methods; Klute, A., Ed.; American Society of Agronomy, Inc.: Madison, WI, USA; Soil Science Society of America, Inc.: Madison, WI, USA, 1986; pp. 363-375.

25. Brady, N.C.; Weil, R.R. The Nature and Properties of Soils, 14th ed.; Pearson Education International: Upper Saddle River, NJ, USA, 2008.

26. Gupta, P.K. Soil, Plant, Water and Fertilizer Analysis; AGROBIOS Publisher: Rajasthan, India, 2004.

27. Rowell, D.L. Soil Science: Method and Applications; Addison Wesley Longman Ltd.: London, UK, 1994.

28. Walkley, A.; Black, C.A. An examination of different methods for determining soil organic matter and the proposed modification by the chromic acid titration method. J. Soil Sci. 1934, 37, 29-38. [CrossRef]

29. Jackson, M.L. Soil Chemical Analysis; Prentice Hall, Inc.: Hoboken, NJ, USA, 1958; pp. 183-204.

30. Bertsch, P.; Bloom, P. Aluminium. In Methods of Soil Analysis; Bigham, J.M., Bartels, J.M., Eds.; Part 3: Chemical Analysis. SSSA Book Series No 5; American Society of Agronomy, Inc.: Madison, WI, USA; Soil Science Society of America, Inc.: Madison, WI, USA, 1996; pp. 517-550 
31. Olsen, S.R.; Cole, C.V.; Watanabe, F.S.; Dean, L.A. Estimation of Available Phosphorous in Soils by Extraction with Sodium Bicarbonate. Circular 1954, 939, 1-19.

32. Baruah, T.C.; Barthakur, H.P. A Textbook of Soil Analysis; Vikas Publishing House. Pvt. Ltd.: New Delhi, India, 1997.

33. Coyne, M.S.; Thompson, J.A. Math for Soil Scientists; Thomson Delmar Learning: Clifton Park, NY, USA, 2006.

34. Lindsay, W.L.; Norvell, W.A. Development of a DTPA soil test for zinc, iron, manganese and copper. Soil Sci. Soc. Am. J. 1978, 42, 421-428. [CrossRef]

35. SAS (Statistical Analysis System). SAS User's Guide: Statistical Released Version 9.3; SAS Institute: Cary, NC, USA, 2008.

36. Tekalign, T. Soil, Plant, Water, Fertilizer, Animal Manure and Compost Analysis; Working document No. 13; International Livestock Research Center for Africa: Addis Ababa, Ethiopia, 1991.

37. Hazelton, P.; Murphy, B. Interpreting Soil Test Results: What Do All the Numbers Mean? 2nd ed.; CSIRO Publishing: Clayton, Australia, 2007.

38. Eyayu, M.; Heluf, G.K.; Tekalign, M.; Mohammed, A. Effects of land use change on selected soil properties in the Tara Gedam Catchment and adjacent agroecosystems, north-west Ethiopia. Ethiop. J. Nat. Resour. 2009, 1, 35-65.

39. Haile, G.; Lemenhi, M.; Itanna, F.; Senbeta, F. Impacts of Land Uses Changes on Soil Fertility, Carbon and Nitrogen Stock under Smallholder Farmers in Central Highlands of Ethiopia: Implication for Sustainable Agricultural Landscape Management around Butajira Area. N. Y. Sci. J. 2014, 7, 27-44.

40. Alemayehu, K.; Sheleme, B. Effects of different land use systems on selected soil properties in South Ethiopia. J. Soil Sci. Environ. Manag. 2013, 4, 100-107.

41. Temesgen, D. Soil Acidity-Induced Land Use/Cover Change and Management Systems on Soil Quality Parameters in the Central Highlands of Ethiopia. Ph.D. Thesis, Sustainable Forest Management Research Institute, University of Valladolid, Valladolid, Spain, 2014.

42. Amacher, M.C.; O’Neill, K.P.; Perry, C.H. Soil vital signs: A new soil quality index (SQI) for assessing forest soil health. Res. Pap. USDA For. Serv. 2007, 4, 240-256.

43. Eyayu, M.; Mamo, Y. The effects of land use types and soil depth on soil properties of Agedit watershed, Northwest Ethiopia. Ethiop. J. Sci. Technol. 2018, 11, 39-56.

44. Habtamu, A.; Heluf, G.; Bobe, B.; Enyew, A. Fertility Status of Soils under Different Land uses at Wujiraba Watershed, NorthWestern Highlands of Ethiopia. Agric. For. Fish. 2014, 3, 410-419.

45. Heluf, G.; Wakene, N. Impact of land use and management practices on chemical properties of some soils of Bako area, western Ethiopia. Agropedology 2003, 13, 1-9.

46. Mengistu, T.; Dereje, T. Selected soil properties under different land uses at Fasha District, Southern Ethiopia. J. Biodivers. Environ. Sci. 2021, 18, 38-47. 